\title{
Income Diversification and its Determinants among Households in Eastern Cape Province, South
} Africa

\author{
*Megbowon Ebenezer Toyin, Mushunje Abbyssiania \\ University of Fort Hare, Republic of South Africa \\ *megbowontoyin@gmail.com
}

\begin{abstract}
Income diversification has been globally identified as a channel for household in reducing vulnerability to shocks, improve standard of living and reduce government fiscal burden. In poverty stricken Eastern Cape Province, the pattern and potential of income diversification for welfare improvement have not been explored. This study aims to examine the pattern of income diversification and investigate the factors that influence income diversification among households in the province. Utilizing the General Household Survey 2014, having 3033 households sampled from the province, the study employed descriptive statistics and Poisson regression model to examine determinants of income diversification. The result revealed that households in the Province are not diversified. It revealed that apart from transfers', majority (51.5 percent) of households in the province obtain income from only one source. Male headed households tend to have more income sources than the female headed households. Regression result indicates age of household head, population group of the head, education attainment of the head, engagement in agriculture, recipient of remittance and number of economic active member of the household were found to be statistically significant in influencing livelihood diversification. Strategies that can help household in the province diversify their income base need to be promoted, continual engagement in agriculture need to be further encouraged, and individuals and households need to be more informed on government entrepreneurship initiatives like the Broad Black Base Economic Empowerment.
\end{abstract}

Keyword: Income Diversification, Eastern Cape Province, Poisson Regression

\section{Introduction}

Poverty and food insecurity are both considered as complex and multidimensional interwoven phenomenon which are causes and effects of various factors that affect and reflect the standard of living of people. Improving individuals and household welfare with respect to reducing/eliminating poverty and food insecurity remains a vital developmental target of the global community. The reduction of poverty, hunger and undernourishment was identified by world governing bodies as a criterion for achieving other 2015 Millennium Development Goals (MDGs); it also remains number one and two agenda in the recently launched 2030 Sustainable Development Goals (SDGs). Currently, the South African government is battling with community, households and individual levels of poverty, inequality and food insecurity. According to StatSA (2014), less than 45.5 percent individuals and 32.9 percent of household are living below the upper bound poverty line set in the country in 2011. Of this population, the Eastern Cape Province was identified as the second province with highest (68 percent) individual poverty head count in the country. Also, report provided by the Eastern Cape Socio Economic Consultative Council (ECSECC) revealed that in 2014, about 56.6 percent of the population were below the lower bound poverty line in the province, 30.5 percent were below the lower bound food poverty line, inequality in the province was 62.5 percent and the human development index was 0.565 . These households and individual are further entangled in debt web such that they have little or no bank savings to fall on when necessary. These statistics reveal developmental challenges prevailing in the province.

However, one of the indispensable targeted elements with positive potential in the fight against poverty, inequality and food insecurity are the livelihoods and livelihood strategies of individuals and households. Lloyd-Jones and Rakodi, (2014) stated that one of the most promising approaches to poverty reduction both in the urban and rural areas of developing countries is to encourage sustainable livelihoods for the poor and the diversification of these livelihoods. This takes account of individuals and households opportunities, resources and the sources of their vulnerability. Omobowale (2014) noted that livelihood systems are at the centre of poverty reduction and food security issues in different policy environments. These livelihoods are described as means of making a living. It comprises of capabilities/skills explored, resources utilized and activities required for a living (Carney, 1998). It involves various activities engaged in and possessions had in 
order to obtain and secure elementary requirements of life and eventually aid the living of people. Livelihood strategies are approaches or method adopted and choices make with respect to the utilization of assets, skills and engagement in activities to achieve livelihood goals. This strategy could be a singular or sole form of strategy (i.e. there is only one source of income, one activity engagement, and asset or skill exploration) or combined or diversified form of strategy (i.e. there are "more than one" income sources, activity engagements, asset or skill being used). Hussein et al. (1998) buttressed that livelihood diversification, migration and agricultural intensification are livelihood strategies employed by rural dwellers to improve their welfare. Hence, livelihood diversification which this study is focused on is entrenched in livelihood strategy.

Livelihood diversification according to Mandal (2014) is defined as the process by which rural households build an increasing diverse portfolio of activities and assets. Sekunmade and Osundare (2014) put is as attempts by individuals and households to find new ways to raise income in order to stay alive, lower all forms of risk and to improve their wellbeing. It occurs when a household unit produces a new product or renders a paid service without ceasing to producing any of the existing ones (Fabusoro et al., 2010). These portfolio of livelihood activities, income sources and asset has been identified as a core factor that influences farmer household economy (Cinner and Bodin, 2010; Liao et al., 2014). It however needed to be mentioned that livelihood diversification is not limited to rural household alone; it is a practice in the urban area also. Mehta (2009) stated that household livelihood diversification can be viewed from two perspectives; i) employment portfolio and ii) income diversification. Employment diversification explains that individuals and households members engage in different alternative choices in labour market and undertake different form of employments both formal and informal, in rural or urban areas as well. Income diversification on the other hand clarifies that individuals and households create non-agricultural income opportunities. Thus, income is sourced from different sources. It however need to be stated that the income from diversifications matter most as compared to employment choices or participation. Several studies (Babatunde and Qaim, 2010; Shehu and Sidique, 2014; Sitienei et al., 2014; Olale and Henson, 2013; Senadza, 2011; Adepoju and Oyewole 2014; Awotide et al., 2012; Mat et al., 2012; Owusu et al., 2011; Awotide et al., 2010) have shown that livelihood diversification have positive impact on household income, poverty, food security and nutrition, expenditure and inequality. Thus, considering the aforementioned background on the welfare situation in the Eastern Cape Province, and the potential impact of livelihood diversification, this study aims to understanding income diversification pattern in the province and its influencing factors. Specifically, the study aims to answer these questions 1) what is the income diversification pattern of households? and 2) what factors influences household income diversification? The paper is organised as follows; following the background is a brief empirical literature review, followed by the methodology. The fourth section present the analysis of data and discussion, the last section is the conclusion and recommendation.

\section{Literature Review}

In literatures, the number of income sources, share of off-farm income and income diversification index have been used as a proxy for income diversification. A study carried out in Ghana by Agyeman et al. (2014), indicates that age of heads of households had a significant negative relationship with diversification (SID), this implies that as heads of farm households increases in age, the less they diversify their income sources. This is as a result of lack of physical strength and financial resources to add on to their farm or Non-farm activities, since a majority of these activities are observed to be labour intensive. In Nigeria and Cambodia, Oyewole et al., (2015), Idowu et al. (2011), Fabusoro et al. (2010) and Kimsun and Sokcheng (2013) presented results of insignificance of age of household head contrary to the findings of Agyeman et al. (2014).

In terms of gender of the household head, gender had negative and significant effect on household income diversification (Awotide et al., 2012), which is in favour of the female headed household. Comparing both urban and rural areas in Vietam, Chuong et al. (2015), found that female headed households, shows to have a statistically significant effects on diversification of income sources in rural areas while they do not in urban areas. Studies are of the opinion that since female lack access to productive resources they resolve to engage in various income activities to meet their daily needs. Household size as a factor is hypothesized to be positively related to income diversification index and number of income sources provided there is higher number of economically active member in the household. Empirical evidence from Javed et al. (2015), Idowu 
et al. (2011) confirmed that household size is significantly and positively influence income diversification. Some other studies Adebayo et al. (2012), Babatunde and Qaim (2009), Khatun and Roy (2014) however found it to be negative and non-significant in influencing income diversification. Findings from the study of Awotide et al. (2012) also show that household size is significant but negatively influence income diversification. Thus, empirical findings present mixed results.

Babatunde anad Qaim (2009), Senadza (2012) and Vimefall (2015) examined the determinants of rural income diversification in Nigeria and Ghana respectively. The studies proxy income diversification by number of income sources. Consequently, the Poisson regression model was applied to achieve their objectives. Result from the study of Babatunde and Qaim (2009) shows that education, having productive assets, access to electricity, pipe-borne water had positive and significant impact on rural household income diversification. Surprisingly, household size, farm size, distance to market and access to credit were found to be insignificant. The positive significance of electricity and pipe-borne water shows the importance of infrastructural endowment however there is no clear link between access pipe-borne water and income diversification. Using a ZIP, the result of Senadza (2012) ascertain the importance of Average years of schooling of household (education), access to electricity on number of income sources. However contrary to the findings of Babatunde and Qaim (2009) distance to market (km), access to credit, farm size, household size and age of household head have significant impacts on number of income sources. Vimefall (2015) Applied a generalized Poisson regression on the determinants of number of income sources among female headed households in Kenya, findings of the study indicates that the number of income sources increases with the number of adults in the household, the level of education, the age of the head of household and the number of children aged 210 years. The study further found out after adding in all controls that having a monogamously married female head of household increases the number of income sources by a factor of 1.115 keeping all other variables constant, and having a widow as head of household increases the number of income sources by a factor of 1.047. Households with monogamously married female heads have more income sources than all other types of female-headed households.

\section{Methodology}

Study Area: The study was carried out in the Eastern Cape Province of South Africa. The Province is one of the nine Provinces in the country and it comprises of six district municipalities. The Province is located on the east coast of South Africa between the Western Cape and KwaZulu-Natal provinces. It borders the Northern Cape and Free State provinces, as well as Lesotho. The Province covers an area of $168,966 \mathrm{~km}^{2}$ which has been considered to be the second-largest province in South Africa by land size. In 2011, the province was estimated to have a population of about 6562053 people which account for about 12.7 percent of South Africa population, the third largest after KwaZulu-Natal and Gauteng Provinces respectively (StatsSA, 2014). Eastern Cape has excellent agricultural and forestry potential. Agricultural census carried out showed that the province has the highest number of household practising agriculture. The metropolitan economies of Port Elizabeth and East London are based primarily on manufacturing, the most important industry being motor manufacturing. The province is the hub of South Africa's automotive industry.

Data Source: Data is from the 2014 General Household Survey of South Africa. The GHS is a nation-wide survey conducted by the Statistic South Africa. A multi-stage design with probability proportional to size was used to identify and select primary sampling units (PSUs) and dwelling units (DUs) (Stat SA, 2015). While 25363 households were interviewed across the country during the exercise, a 93.7 percent response rate was achieved during the survey. The GHS gathered information on demographic characteristics of households and individuals, access to public assets, ownership of private assets, household welfare, and household livelihoods among others. Eastern Cape Province which is the study area of the paper has 3033 household that were sampled and 96.9 percent response rate was recorded.

\section{Analytical Approach}

Descriptive: Descriptive analytical methods such as frequency counts, percentages and tables were used to analyse some socioeconomic and demographic variables and income diversification pattern of household respondents. 
Poisson Regression Model: Poisson regression is often applied when the dependent variable is a count variable, which in this case number of income sources is a count variable. Hence, following Senadza (2012), Poisson regression was used in identifying factors that does influence income diversification. The Poisson model specifies that $y_{i}$ (number of income sources) is drawn from a Poisson distribution (not the normal or logistic distribution) with parameter $\left(\lambda_{\mathrm{i}}\right)$, which is the mean of number of income sources and related to a set of explained variables $\left(\mathrm{X}_{\mathrm{i}}\right)$. According to Greene (2003), the general primary equation of a Poisson model reflecting it probability function or density function is;

$\operatorname{Prob}\left\{Y_{i}=y_{i} \mid x_{i}\right\}=\frac{e^{-\lambda_{\lambda} y i}}{y_{i} !}, y_{i}=0,1,2$

With mean,

$E\left(y_{i} \mid X_{i}\right)=\lambda_{i}=\exp \left(X_{i}^{\prime} \beta\right)=\exp \left(\beta_{0}+\beta_{i} x_{i i}+\beta_{2} x_{2 i}+\cdots+\beta_{k} x_{k i}\right) \ldots$

The estimation form of the regression model for Poisson variable is;

$y_{i}=\lambda_{i}=\exp \left(X_{i}^{\prime} \beta\right)+\varepsilon_{i}=\exp \left(\beta_{0}+\beta_{i} x_{i i}+\beta_{2} x_{2 i}+\cdots+\beta_{k} x_{k i}\right)+\varepsilon_{i} \ldots(3)$

Where $\mathrm{y}$ is the number of income sources proxy for income diversification, and $\mathrm{x}_{\mathrm{i}}$ is the set of independent variables determining income diversification. These include, sex of household head (male $=1,0=$ otherwise), age (years), education attainment, marital status (living together $=1,0=$ otherwise), access to electricity (yes $=1,0=$ otherwise), engagement in agriculture (yes $=1,0=$ otherwise), recipient of remittance (yes $=1,0=$ otherwise), pension(yes $=1,0=$ otherwise), households' size (number), size economic active member of the household and geographical location (urban=1, $0=$ otherwise).

\section{Analysis and Discussion}

Number of Income Sources, and Distribution of Diversification Status by Household Socio-economic Characteristics: A descriptive analysis of livelihood diversification in the Eastern Cape Province of South Africa is presented in tables 1 and 2. This is discussed with reference to number of income sources and the diversification status. Households with more than one income sources is considered as diversified and vice versa. The main income sources of households are salaries, income from business, agriculture income, remittance, pension, grants and income from other sources like rent, interest and dividends. Information obtained from the 2014 GHS revealed that majority (41.74) of the households get income from grants, the type of grant is however no explored. Going by this study definition of income diversification, income from remittance, pension and grants were excluded.

Table 1: Distribution of Households by Number of Income Sources

\begin{tabular}{lll}
\hline Number of Income Sources & Number of Households & Percent of Household \\
\hline 0 & 1318 & 43.46 \\
1 & 1551 & 51.44 \\
2 & 154 & 5.08 \\
3 & 10 & 0.33 \\
\hline
\end{tabular}

Source: Author's Computation from GHS 2014

Table 1 revealed further that the number of income sources by household in the province ranges between zero and three but only 5.41 percent of households sampled are having more than one income sources. It could be said that households in the province are absolutely not diversified.

Distribution of diversification status by households' characteristics is presented in Table 2. A household is considered diversified if it has more than one income sources. The table shows that a higher proportion of male headed household are considered diversified (67.68 percent) than the female headed households (32.32 percent). On the hand a higher proportion of female headed households are in the "not diversified" category. In the age of household head category, households with head between the age 41 and 60 years are seen to have the highest in both diversified (60.37 percent) and not diversified (38.9 percent) groups. It is worrisome to see that about 91.9 percent of household head in the most active age group are not having more than one income source or not having any income at all. Also, the table revealed that households having heads living together are considered diversified followed by singles and households that have widowed heads. However 
considering each of the household head marital status group, almost more than 90 percent of households of each group are not diversified.

Similar trend is observed in the household size group with respect to the proportion of households in each of the group that are not diversified. Specifically, 94.8 percent, 94.1 percent, 96.6 percent and 91.4 percent are considered not diversified by each of the household size group. However household size groups of 1 to 3 members and 4 to six members are the highest proportion of household size considered to be diversified. The role of education in livelihood diversification is buttressed in literature as providing skill and opportunity for entrepreneurship and to engage in other income generating activities. It is shown from the table 6.3 that households with a head attaining secondary education are more (50 percent) represented in the diversified group followed by household with heads with primary education (24.4 percent). Considering row-wise analysis of education attainment of the head, it is seen that expect for the household with head that attained a secondary education having 74.7 percent of households that not diversified, all other education attainment group have more that 90 percent of households that are not diversified.

It can be assumed that having a secondary education increases that chance of entrepreneurship of the household head. This is seen from the information further generated in the GHS that about 64.9 percent of households obtaining income from business have a head with secondary education. Geographical location is in no doubt important for livelihood diversification. In urban area where there is much population and economic activities, individuals and households have opportunity in engaging in multiple income generating activities that the rural areas. Among the considered diversified group, there is almost an equal geographical representation of household as 53.1 percent and 46.95 percent are located in the urban and rural area respectively. A row-wise check on the "not diversified" category revealed a similar trend like that of marital status and household size where majority of the household are not diversified. In the geographical location category, 94.1 percent and 95.1 percent of households are considered not diversified in the urban and rural area respectively. In general, households in the province cannot be said to be diversified. This is however not the case as seen in studies carried out in other part of Africa

Table 2: Distribution of Households by Diversification Status

\begin{tabular}{|c|c|c|c|c|c|}
\hline $\begin{array}{l}\text { Household } \\
\text { characteristics }\end{array}$ & & $\begin{array}{l}\text { Not } \\
(\%)\end{array}$ & Diversified & $\begin{array}{l}\text { Diversified } \\
(\%)\end{array}$ & Total (\%) \\
\hline \multicolumn{6}{|c|}{ Sex of Household Head } \\
\hline & Male & 48.7 & & 67.68 & 49.79 \\
\hline & Female & 51.24 & & 32.32 & 50.21 \\
\hline \multicolumn{6}{|c|}{ Age of Household Head } \\
\hline & $\leq 40$ & 27.68 & & 19.51 & 27.23 \\
\hline & $41-60$ & 38.90 & & 60.37 & 40.06 \\
\hline & $61 \geq$ & 33.43 & & 20.12 & 32.71 \\
\hline \multicolumn{6}{|l|}{ Marital Status } \\
\hline & Living Together & 37.72 & & 62.8 & 39.80 \\
\hline & Divorced & 2.69 & & 3.66 & 2.74 \\
\hline & Separated & 3.49 & & 3.05 & 3.47 \\
\hline & Widowed & 25.61 & & 14.63 & 25.02 \\
\hline & Single & 30.50 & & 15.85 & 29.70 \\
\hline \multicolumn{6}{|l|}{ Household Size } \\
\hline & $1-3$ & 53.50 & & 51.83 & 53.41 \\
\hline & $4-6$ & 33.67 & & 37.20 & 33.86 \\
\hline & $7-9$ & 9.86 & & 6.10 & 9.66 \\
\hline & $10-18$ & 2.96 & & 4.88 & 3.07 \\
\hline \multicolumn{6}{|c|}{ Educational Attainment of Head } \\
\hline & No Education & 11.06 & & 6.10 & 10.79 \\
\hline & Primary & 32.52 & & 27.44 & 32.24 \\
\hline & Secondary & 45.67 & & 50.0 & 45.91 \\
\hline & Certificate and Diploma & 6.49 & & 6.10 & 6.47 \\
\hline & Higher Degree & 4.26 & & 10.37 & 4.59 \\
\hline
\end{tabular}




\begin{tabular}{rrrr}
\hline Geographical Location & & & \\
Urban & 48.14 & 53.05 & 48.40 \\
Rural & 51.86 & 46.95 & 51.60 \\
Engagement in Agriculture & & & \\
Yes & 37.19 & 51.83 & 37.98 \\
No & 62.81 & 48.17 & 62.02 \\
\hline
\end{tabular}

Source: Author's Computation from GHS 2014

Factors Influencing Household Livelihood Diversification: Poisson regression model was fitted in order to estimate factors that influences livelihood diversification. The count of number of income generating sources served as the explained variable while a number of explanatory variables were examined. The independent variables considered for this model are household head characteristics (sex, age, education attainment, and marital status), access to electricity, engagement in agriculture, recipient of remittance, pension, and households' size, number of economic active member of the household and geographical location (urban). In addition to the estimated model, marginal effect of each independent variable on the dependent variable (number of income sources) and multicollinearity test to check the consistency and biasness of the estimated was further examined. The mean VIF of the multicollinearity test was found to be 1.29 and none of the individual variables have a VIF value above 5.00, and the tolerance level of 77.5 percent indicates the absence of any serious multicollinearity. Table 3 shows that of the eleven variables examined in the model, six variables (age of household head, population group of the head, education attainment of the head, engagement in agriculture, recipient of remittance and number of economic active member of the household) were found to be statistically significant.

At one percent level, the age of the household heads parameter was found to statistically influence income diversification of households head negatively. The marginal effect of the variable has a value of -0.005 . This implies that a unit decrease in the age of household heads leads to 0.5 percent decrease in the number of income sources. This suggest that as the household heads' increase

Table 3: Poisson Regression Estimate

\begin{tabular}{llllll}
\hline Variables & Coefficients & $\begin{array}{l}\text { Standard } \\
\text { Error }\end{array}$ & $\mathbf{Z}$ & P-Values & Marginal Effect \\
\hline Constant & -0.6121 & 0.1604 & -3.82 & 0.000 & \\
Age of household head & -0.0102 & 0.0018 & -5.80 & $0.000^{*}$ & -0.0050 \\
Sex of household head & 0.0367 & 0.0490 & 0.75 & 0.454 & 0.0181 \\
Population Group & -0.0699 & 0.0302 & -2.32 & $0.020^{* *}$ & -0.0344 \\
Education of head & 0.0845 & 0.0275 & 3.07 & $0.002^{*}$ & 0.0416 \\
Access to electricity & -0.0938 & 0.0780 & -1.20 & 0.229 & -0.0462 \\
Engagement in Agriculture & 0.1613 & 0.0611 & 2.64 & $0.008^{* *}$ & 0.0810 \\
Receive remittance & -0.4665 & 0.0773 & -6.04 & $0.000^{*}$ & -0.2019 \\
Receive pension & -0.1067 & 0.1208 & -0.88 & 0.377 & -0.0501 \\
Household Size & 0.0043 & 0.0094 & 0.46 & 0.647 & 0.0021 \\
Economic Active Size & 0.6300 & 0.0244 & 25.87 & $0.000^{*}$ & 0.3101 \\
Urban & 0.0575 & 0.0618 & 0.93 & 0.352 & 0.0283 \\
\hline
\end{tabular}

Source: Result Generated from STATA 12.

*** indicate significant at 1 percent and 5 percent level of significance in age, ageing and other associated health challenges come in the head becomes less economically productive. The households' heads' ability to engage in other income generating activities becomes limited due to health status and diminishing physical strength.

Though the result is not in conflict with theoretical expectation and the findings of Senadza (2012), it is however contrary to the findings of Babatunde and Qaim (2009), and Vinefall (2015) who both found age of household head to be insignificant and significantly positive in Nigeria and Kenya respectively. The importance of education of a household generally and the head especially is ascertained by the result in Table 3. Education promote job mobility and skill acquisition that could be needed to engage in other economic activities. Education attainment of the head as shown in the Table 3 indicates a significant positive 
relationship with number of income sources (proxy for income diversification) at one percent level. This shows that higher the level of education of the head the higher will be the probability of the household in getting income from other sources. This corroborates the result from the studies of Babatunde and Qaim (2009), Senadza (2012) and Vimefall (2015). The marginal effect of the education attainment of head variable of 0.0416 implies that a unit increase in the education attainment result in 4.1 percent increase in the number of income sources in the household. The probability of agricultural activities in increasing the number of income sources of a household is shown in the result of positive and significant coefficient of the variable at 10 percent in Table 3. The marginal effect result of 0.081 implies that a unit increase in participation in agriculture will increase the number of income sources by 8.1 percent.

Of the two transfer indicators examined (remittance and pension) in the model, only remittance indicates a significant relationship with income diversification. Table 3 shows that remittance variables has a negative influence on income diversification. The marginal effect result of -0.2019 implies that income diversification of households will reduce by 20.2 percent for a unit increase in remittance received by the household. This is contrary to the result of Sanadza (2012), who found an insignificant relationship between number of income sources and remittance recipients in Ghana. In reference to the influence of number of economic active member in the household on income diversification, the estimated result of the variable perform as expected, showing a very significant positive relationship with number of income sources (proxy for income diversification). In addition, the marginal effect estimate indicates 31 percent increase in the probability of a household diversifying her income sources as a result of a unit increase in the number of household that are economically active. It is surprising to see that access to electricity by household is considered as a public asset that could stimulate increase income sources with respect to engagement in entrepreneurship activities by individuals and household.

\section{Conclusion and Recommendation}

Livelihood diversification is important in the fight against persistent poverty in sub-Saharan Africa, including South Africa. This study investigates livelihood diversification and its determinants in the Eastern Cape province of South Africa. The study deduces that households in the province are inactive towards income diversification. This study advocates for formal or informal education training programmes for household heads and other adult members in order to improve their knowledge and skill acquisition for labour involvement and entrepreneurship coupled with mentorship and monitoring for successful entrepreneurship. Individuals and households need to be more informed on government entrepreneurship initiatives like the Broad Black Base Economic Empowerment. Furthermore, there is need for further enlightenment of households on the benefits of engaging in agriculture seeing that it has potential in enhancing household capability to diversifying its income base and improving their welfare consequently. This should be backed with continual development support in agricultural activities. Likewise, incentives or government assistance with conditions that will motivate households to income diversification could be adopted in the short term.

\section{Reference}

Adebayo, C., Akogwu, G. O. \& Yisa, E. (2012). Determinants of Income Diversification Among Farm Households In Kaduna State: Application Of Tobit Regression Model. PAT, 8(2), 1-10

Adepoju, A. 0. \& Oyewole 0. 0. (2014). Rural Livelihood Diversification and Income Inequality in Local Government Area Akinyele, Ibadan, Oyo state, Nigeria. Journal of Agricultural Sciences, 59 (2), 175186.

Agyeman, B. A. S., Samuel, A. \& Edward, E. O. (2014). Determinants of Income Diversification of Farm Households in the Western Region of Ghana. Quarterly Journal of International Agriculture, 53 (1), 5572.

Awotide, O., Adetunji K. \& Agbola, P. (2010). Poverty and Rural Livelihood Diversification among Farming Households in Southwest Nigeria. Journal of Food Agriculture and Environment, 8(1), 367-371.

Awotide, B. A., Awoyemi, T. T., Diagne, A., Kinkingnihoun, F. M. \& Ojehomone, V. (2012). Effect of Income Diversification on Poverty Reduction and Income Inequality in Rural Nigeria: Evidence from Rice Farming Households. OIDA International Journal of Sustainable Development, 5(10), 65-78. 
Babatunde, R. \& Qaim, M. (2009). Patterns of Income Diversification in Rural Nigeria: Determinants and Impacts. Quarterly Journal of International Agriculture, 48(4), 305-320

Babatunde, R. O. \& Qaim, M. (2010). Impact of Off-Farm Income on Food Security and Nutrition in Nigeria. Food policy, 35(4), 303-311.

Carney, D. (1998). Implementing the Sustainable Rural Livelihoods Approach. Paper presented at DFID Natural Resource Advisers Conference, 5-9 July.

Chen, S. \& Ravallion, M. (2013). More Relatively-Poor People in a Less Absolutely-Poor World. Review of Income and Wealth, 59(1), 1-28.

Chuong, O., Thao, N. \& Ha, T. (2015). Rural Livelihood Diversification in the South Central Coast of Vietnam. Mekong Economic Research Network (MERN).

Cinner, J. \& Bodin, O. (2010). Livelihood Diversification in Tropical Coastal Communities: A Network-based Approach to Analyzing Livelihood Landscapes. PloS one, 5(8), 1-13.

Fabusoro, E., Omotayo, A., Apantaku, O. \& Okuneye, P. (2010). Forms and Determinants of Rural Livelihoods Diversification in Ogun State, Nigeria. Journal of Sustainable Agriculture, 34(4), 417-438.

Food and Agriculture Organization, International Fund for Agricultural Development \& World Food Programme (2014). The State of Food Insecurity in the World 2014. Strengthening the enabling environment for food security and nutrition. Rome, FAO.

Greene, W. (2003). Econometrics analysis. Prentice Analysis, New Jersey.

Hussein, K., Nelson, J. \& University of Sussex. Institute of Development Studies (1998). Sustainable Livelihoods and Livelihood Diversification, Working Paper, 69, Institute of Development Studies, University of Sussex, Brighton, England.

Javed, S., Abdul M. N., Muhammad Z. R. \& Muhammad A. K. (2015). Determinants of Income Diversification among Rural Households of Pakistan. Journal of Economics and Sustainable Development, 6(14), 4549.

Idowu A., Aihonsu, J., Olubanjo, O. \& Shittu, A. (2011). Determinants of Income Diversification amongst Rural Farm Households in South West Nigeria. Economics and Finance Review, 1 (5), 31-43.

Khatun, D. \& Roy, B. (2012). Rural Livelihood Diversification in West Bengal: Determinants and Constraints. Agricultural Economics Research Review, 25(1), 115-124.

Kimsun, T. \& Sokcheng P. (2013). The Role of Income Diversification During the Global Financial Crisis: Evidence from Nine Villages in Cambodia (No. 78). Working Paper Series.

Liao, C. \& Barrett, C. B. \& Kassam, K. S. (2014). Does Diversification Translate Into Improved Livelihoods? Evidence from Pastoral Households in the Altay and Tianshan Mountains of Xinjiang, China. http://dx.doi.org/10.2139/ssrn.2628701

Lloyd-Jones, T. \& Rakodi, C. (2014). Urban livelihoods: A people-centred approach to reducing poverty. Routledge.

Mandal, R. K. (2014). Level of Living and Livelihood of Rural Tribal People in Arunachal Pradesh: A Case Study. Galaxy International Interdisciplinary Research Journal, 2(2), 18-31

Mehta R. (2009). Rural livelihood Diversification and Its Measurement Issues: Focus India. Wye City Group on Rural Statistics and Agricultural Household Income, Second Annual Meeting, 11-12 June 2009, FAO, Rome

Mat, S. H. C., Jalil, A. Z. A. \& Harun, M. (2012). Does Non-Farm Income Improve the Poverty and Income Inequality among Agricultural Household in Rural Kedah? Procedia Economics and Finance, 1, 269275.

Olale, E. \& Henson, S. (2013). The Impact of Income Diversification among Fishing Communities in Western Kenya. Food Policy, 43, 90-99.

Omobowale, A. O. (2014). Livelihood, Agro Ecological Zones and Poverty in Rural Nigeria. Journal of Agricultural Science, 6(2), 103.

Owusu, V., Abdulai, A. \& Abdul-Rahman, S. (2011). Non-farm Work and Food Security among Farm Households in Northern Ghana. Food policy, 36(2), 108-118.

Oyewole, S. O., Adepoju S. O. \& Akintola, A. L. (2015). Analysis of Income Diversification Strategies among Farm households in Oyo State. Journal of Economics and Sustainable Development, 6 (15), 109-112.

Sitienei, I., Mishra, A. K., Gillespie, J. \& Khanal, A. R. (2014). Participation in Informal Off-Farm Labor Market and Its Impact on Household Income and Food security in Malawi (No. 162498). Southern Agricultural Economics Association. 
Shehu, A. \& Sidique, S. F. (2014). A Propensity Score Matching Analysis of the Impact of Participation in NonFarm Enterprise Activities On Household Wellbeing In Rural Nigeria. UMK Procedia, 1, 26-32.

Sekunmade, A. \& Osundare, F. (2014). Determinants and Effect of Livelihood Diversification on Farm Households in Ekiti State, Nigeria. Journal of Economics and Sustainable Development, 5(5), 104-110.

Senadza, B. (2011). Does Non-farm Income Improve or Worsen Income Inequality? Evidence from Rural Ghana. African Review of Economics and Finance, 2(2), 104-121.

Senadza, B. (2012), Non-farm Income Diversification in Rural Ghana: Patterns and Determinants. African Development Review, 24(3), 233-244

Statistics South Africa. (2015). General Household Survey 2014; Statistics South Africa: Pretoria, South Africa, Available online:www.statssa.gov.za/publications/P0318/P03182014.pdf

Statistics South Africa. General Household Survey 2014 [dataset]. Version 2. Pretoria. Statistics South Africa [producer], Cape Town. [distributor], http://www.datafirst.uct.ac.za/dataportal/index.php/catalog/192.

Vimefall, E. (2015). Income Diversification among Female-Headed Farming Households (No. 2015: 11). Örebro University, Orebro University School of Business, Örebro University, Sweden.

World Bank Group. (2015). Global Monitoring Report 2014/2015: Ending Poverty and Sharing Prosperity. Washington, DC: World Bank. 